\title{
THE TALE OF WALLAMBAIN AND PHILCHOWSKI
}

\author{
Bruce Shaw
}

One of the better-known tales of the Kununurra district tells how in 1913 a European émigré named Rudolph Philchowski was speared to death by an Aboriginal called Wallambain. The story appears in written European sources; it is also passed on in local Aboriginal oral tradition. Hence it is well suited for showing some of the advantages in having available oral and written versions of the one incident, of having both 'anthropological' and 'historiographical' materials at hand. As well as this methodological consideration there is the importance of the story itself. Taken alone it might be a relatively minor footnote to our knowledge of Aboriginal history. But it belongs in fact to a distinctive genre of frontier tale. Wallambain shares a place with others like Major (died 1908), Nemarluk (died 193246) and Pigeon (died 1897) as an outlaw figure in our stories of Aboriginal resistance. ${ }^{1}$ Wallambain's story will be retold by amalgamating the different oral and written versions roughly along the lines of the tale of Major written up some years ago. ${ }^{2}$

The two written versions of the tale come from the same pen, that of the Western Australian author Mary Durack. They are separated by more than forty years and so contain slightly different subject matter and interpretations. They cannot be considered as independent accounts however because the second version clearly built upon the first. The first was a newspaper article published in 1931 under the title 'Rudolph Philchowski: tale of a northwest tragedy'. ${ }^{3}$ The later version appears in the second of Durack's family histories Sons in the saddle and draws upon the diaries of her father Michael Patrick (M.P.) Durack in particular and an Aboriginal account from her informant and friend Johnny Walker. ${ }^{4}$

I recorded three oral versions during fieldwork in Kununurra from 1973 to 1974 and confirmed them at proof-reading sessions in subsequent years. The longest came from Johnny Walker, Mary Durack's source. So we have two different accounts from one person told from an Aboriginal perspective. My other two Aboriginal sources were Banggaldun Balmirr and

Bruce Shaw taught anthropology at the Darwin Community College (now the Darwin Institute of Technology) from 1976 to 1983. He did fieldwork, using life-history methodology, in the east Kimberley and now does consultancy work with Aboriginal communities and with the Aboriginal Heritage Branch of the South Australian Department of Environment and Planning. During 1988 he is a research scholar with the Australian Institute of Aboriginal Studies.

1 For Pigeon's story see Muecke, Rumsey and Wirrunmarra 1985, and Pedersen 1984; for Nemarluk see Pye 1973. See also Shaw's articles on Major and Nemarluk forthcoming in the Northern Territory Dictionary of Biography.

2 Shaw $1983 \mathrm{~b}$.

3 Mary Durack's sources on this occasion were the oral testimonies of white people who lived in the district in 1913, including her father M.P. Durack, her mother Bess, Bill Jones, and a family friend named Charlie Flinders (personal communication Mary Durack). Mary herself was born that year in Adelaide.

4 Durack 1983:287-90. 


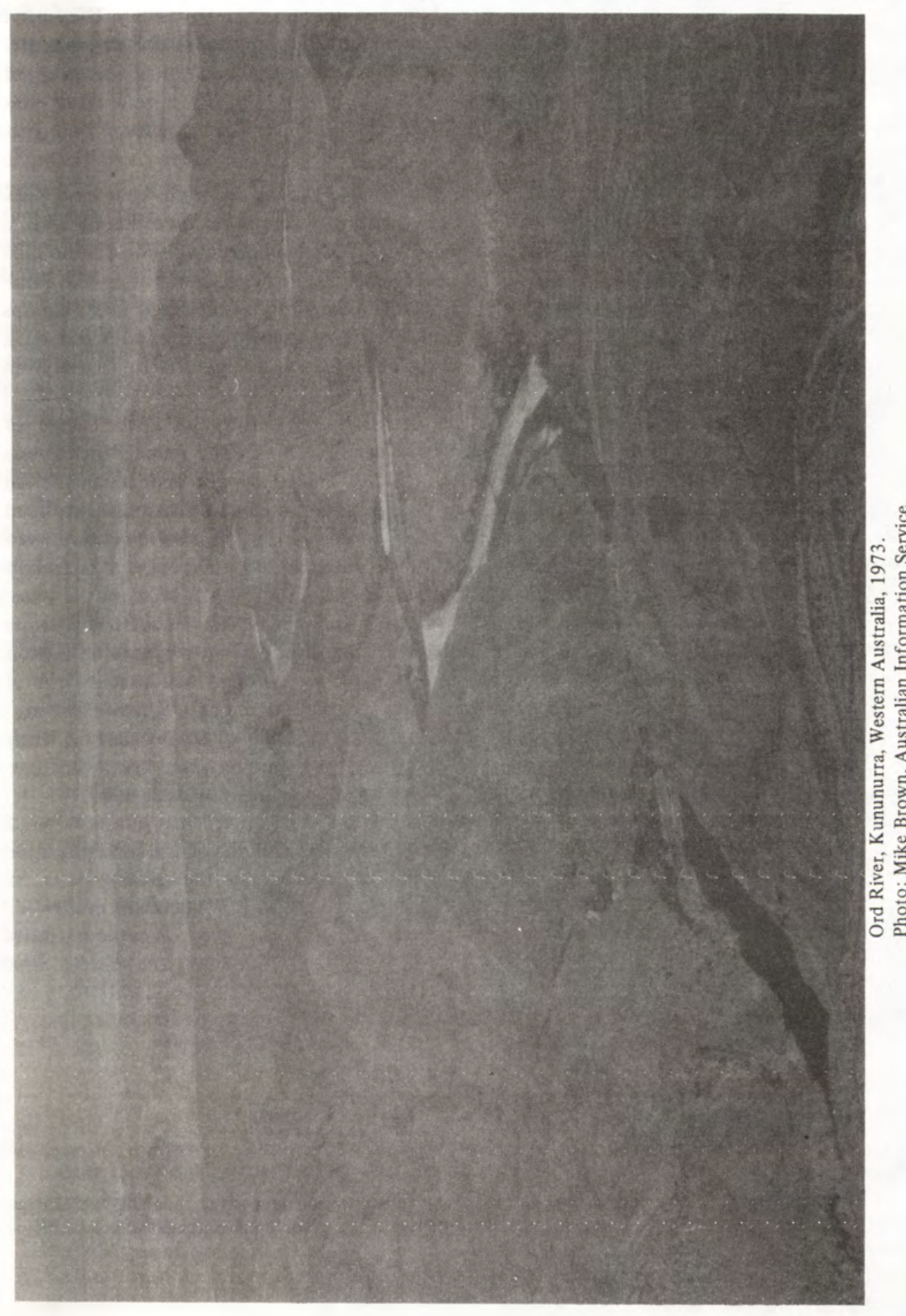


Jack Sullivan. Both of their versions are short. Banggaldun's story is fragmentary. They have been edited into the published memoirs of both men, ${ }^{5}$ but they are used little here as source material. I prefer to go back to the original transcripts for that purpose.

\section{The Tale.}

\section{Background to Philchowski.}

Little is known about Philchowski's European origins. Durack reported what were probably local speculations among the whites of the district as well as her own that he was 'a Count of the German Aristocracy', who evidenced 'education and breeding', and that he had fled his home country 'following a political disagreement with the Kaiser'. ${ }^{6}$ Men like Philchowski were often found on Australia's frontiers. The anonymity of the single men's camps offered havens for those seeking to leave behind an unsatisfactory past (as they still do). Moreover, wars and economic depression in Europe stimulated immigration to Australia in the early decades of this century.

Stock records and popular books about the east Kimberley reflect this in the names of station employees, for example, Sullivan, Drugamuller, McKenzie. The name Philchowski is not in fact of German origin. It is Polish. And in Poland it was not uncommon for an ordinary citizen to purchase the title of Count upon settling into a new district. Poland had many Counts (personal communication, an 'ethnic' writer). From an Australian point of view however anyone whose name and nationality was Austrian or Polish, etc. was probably designated German.

By all accounts Philchowski had been living in the Wyndham district 'a good many years before the war broke out, ${ }^{7}$ so he was a well-known identity. He ran a store at Carlton Reach, a place on the Ord River south of present-day Kununurra from which he sold alcohol and procured Aboriginal women for white travellers, according to Johnny Walker's communication to Mary Durack. ${ }^{8}$ This shows that he had a relationship of some standing with Wallambain and probably other Aborigines of the area. It is commonly held in criminology that a very high percentage of homicides occur between people who know each other.

Philchowski in fact lost his job through those activities. M.P. Durack had him dismissed because of the delays in store deliveries caused by teamsters dallying at the place. ${ }^{9}$ Later Philchowski had the mail run from the port of Wyndham to several of the cattle stations. It may have been on one of these mail runs that the incident with Wallambain occurred, though this is not clear. He is otherwise characterised as 'workin all over' on cattle stations such as Ord River Station and Rosewood. ${ }^{10}$

Shaw 1983a:70 and 1986:62.

6 Durack 1931.

7 Durack 1931.

8 Mary Durack suggests that Philchowski's store was probably more substantial than the two canvas tents and bough shed where purportedly he lived and kept his liquor supplies (personal communication).

9

Durack 1983:289.

10 Shaw and Walker 1975:46. 


\section{Prelude to the incident.}

The events which led up to the spearing of Philchowski had their beginnings at Rosewood where he was in the company of a man named Jim Crisp who, in turn, was speared to death some years later. ${ }^{11}$ Crisp proposed that they stay at Rosewood a couple of nights and then work and travel together but Philchowski preferred to head off immediately to Wyndham. Johnny Walker detailed the route that he followed: from Rosewood to Argyle Downs Station, to Hicks's Creek on Argyle, to Thompson Spring, Cockatoo Spring, and the Eight Mile creek. This was part of the old cattle droving route to Wyndham. Philchowski made his camp in the locality of the. Eight Mile between the present-day bitumen road and the old stock road. There is a creek in this area today named Philchowsky's Crossing.

Durack's newspaper story recounts that on a July morning Philchowski stopped briefly at Ivanhoe Station and said that he was on his way to Spring Creek Station. Presumably he was coming from Wyndham, travelling in the opposite direction from that given in Johnny Walker's 1975 version. In the Durack version Johnny said that Philchowski went with a man called Joe Fagan to Spring Creek and then took on the mail run. ${ }^{12}$

\section{Discovery of the body.}

The circumstances of the spearing were not clear in the earliest written accounts because they were unknown. They are revealed later from Aboriginal sources. The newspaper version describing Jim Crisp's discovery of Philchowski's body has a dramatic quality which is most likely Durack's. In Crisp's eye-witness account as reported by Durack:

There was the billy near the ashes of a fire, and the camp pitched under a large iron-wood tree, behind the trunk of which a man was lying upon the ground. Jim came nearer, and, as the figure remained motionless, decided that the fellow was sound asleep. 'It's Philchowski,' he said to himself, and called his greeting, hoping to rouse him from his dreams. But the slumber was too deep. 'Hello, Phil, old chap!' he cried again. The words died from his lips. A pool of blood had trickled down upon the sand, staining the golden grass with its crimson hue. He bent and touched the prostrate form. The handle of a spear was protruding from the back of the shoulder, and it was only then that he realised the truth. Philchowski was stone dead.

Johnny Walker might well have heard this description from Crisp, and Johnny might also have been one of Durack's earlier sources (as well as a source for her later version) because both versions are very similar.

He look, he can see the, see the calico, what they covered him over with the old broken calico. Seen all the pack there and saddle, everything, an lyin about any way ... 'What this?' . . . He standin on horseback. 'Hey, you avin a good sleep?

11 Jim Crisp's death is reported in Durack 1983:360-61 and in Johnny Walker's memoirs (Shaw 1987: 191-4), so we have another tale, only very much briefer, from European sources and in oral (Aboriginal) testimony.

12 Mary Durack's notebook records that an Irishman called Joe Fagan took up Spring Creek Station and that Philchowski formed a kind of partnership with Fagan after his (Philchowski's) dismissal from Carlton Reach. At the same time Philchowski ran the mail service between Wyndham and Halls Creek (personal communication). 
Hey, you avin a good sleep?' . . . e jumped off. He lift the calico. He said, 'Hey you avin a good sleep? What's wrong with you?' He lift the cal- Oh goodness almighty, thousands a blue flies come out of it. An e look properly, the man got killed!... 13

Crisp rode in haste to Ivanhoe Station to tell the news: 'By this time it was almost dark, and, crossing to his own camp, Jim saddled up his horse and rode wildly through the night to Ivanhoe." 14 'E jumped on, oh e never stopped. He drove the horses there sixty miles an hour, seventy mile an hour must be. Drivin them to report to Billy Jones. E was manager ..., 15

This is corroborated by M.P. Durack's diary. Dated 25 June (the 1931 newspaper article gives July) 1913, it reads tersely:

About 11.30 last night Jim Crisp arrived on his way down from Auvergne. He reports that he found the body of a man he believes to be Philchowski at the Eight Mile, evidently killed by blacks. Jones, Montgomery, self and three boys proceed to the scene of the murder. Found the body as described by Crisp, spear wound in back of shoulder. Held inquest. Returned verdict of wilful murder. Buried the body close by ... 16

\section{The spearing.}

For the circumstances of the spearing itself we must turn largely to the oral versions which here come into their own. In the tale as told to Mary Durack by Johnny Walker, Philchowski was approached by an Aboriginal man named Wallambain (Woolambine) soon after he made camp at the Eight Mile. Perceiving Philchowski as a friend Wallambain asked for gifts of food and tobacco. This request Philchowski dismissed peremptorily with a verbal insult. Wallambain left in anger, made plans to kill Philchowski, approached him with stealth, speared him in the back and so the deed was done. This is common, with relatively minor differences, to all the versions.

In the version told to me by Johnny Walker the setting up of Philchowski's camp was described in fair detail: choice of site, making of the fire, laying out eating utensils, etc. Wallambain's approach came next, also given at length: attempts by his friends to dissuade him from going, the verbal interchange between the two men, and Wallambain's rebuff. Wallambain then returned to his companions and made his preparations (sharpening the spearhead) while they remonstrated with him. And as in Durack's version he then speared Philchowski while he sat reading a newspaper beneath a forked tree. The dying man fired several shots from his revolver.

In Jack Sullivan's briefer account the firing of the revolver comes at the beginning of the tale under different circumstances. In Jack's version Philchowski came upon a group of

13 Shaw and Walker 1975:51. As part of the preparation for this article I re-transcribed the WallambainPhilchowski narratives given by Johnny Walker, Banggaldun and Jack Sullivan. In due course transcription errors were uncovered but of a 'punctuation' type where I had (perhaps intentionally) missed a word or phrase that was repetitive. Two exceptions in Johnny Walker's version are a confusion between 'swears' and 'swings', and I missed the word 'limb'.

14 Durack 1931.

15 Shaw and Walker 1975:51.

16 Durack 1983:287. 
Aborigines clustered beneath a boab tree at the camp site. He rode down upon them drunkenly firing into the air to scatter them, and it was this belligerent act which precipitated Wallambain's retaliation.

There are some differences of opinion on the way in which Philchowski was speared. Jim Crisp in the source already cited reported that the spear was left in the dead man's back. Johnny Walker stated just as certainly: 'I s'pose when e tap im e pull the spear out and e run away .. See e never left no spear on it. You understand? E might be, go through here, like up here some way. $\mathrm{Hm}$ ? A shovel spear y'know, very very y'know very shovel iron'. ${ }^{17}$ M.P. Durack's diary entry supports this. And Banggaldun in his version stated that: ' $E$ biin sneak up. That man e was siddown like this, readin book. Oh well e come too [very] close. Put a shovel spear ere ... E's come, shovel spear right through [meaning through the fork of the tree]. ${ }^{, 18}$

Irrespective of whether the spear was thrown or thrust or whether more than one spear was brought into play as in Jack Sullivan's narrative, the versions agree on the accuracy of the death stroke. It might be fair to say that such differences reflect inaccuracies in the transmission of the tale but that they do not otherwise tell us much one way or the other about the various cultural assumptions behind them.

\section{Events immediately after the killing.}

Nearly all versions agree on what took place next. Foodstuffs and other items in Philchowski's camp were disturbed, scattered about or destroyed. The European version of 1931 makes much of this, though such details are omitted from Durack's later version. In the newspaper article:

The natives had not come there for food. Bread, meat and onions were strewn haphazardly about. Tea and canned goods, of unknown value to them, had been emptied out upon the ground. The girths and saddles of the dead man's horses were slashed about in sheer wantonness. ${ }^{19}$

The destruction of material goods in stories of this kind appears in European eyes almost as heinous as the crime of killing. It is interesting that by this time in the white takeover of the east Kimberley some Aborigines did not yet appreciate the value of tinned goods and tea. Settlement began three decades earlier around 1880. In Johnny Walker's longer version the use of bottle-glass for spear-heads is mentioned when a different group of Aborigines visited the dead man's camp through the curiosity of some of their womenfolk:

They took everything what they can, what they can think like. All the tomato sauce they spill it. Waterberry [Worcester?] sauce they spill it. Pickle bottle they spill it. Chutney bottle they spill it. They didn't want it. They didn't know how to eat it, you understand? Now they wouldn't spill it . . But why they spill them stuff for, because they want the bottle for spear head. ${ }^{20}$

17 Shaw and Walker 1975:109.

18 Shaw and Balmirr 1982:164.

19 Durack 1931.

20 Shaw and Walker 1975:50. 
The food is not mentioned by Banggaldun. Jack Sullivan made a passing reference to it: 'they put the spears into im an, took all eat everything, the bone, tucker an everything. Leftim with none, ${ }^{, 21}$ which suggests that some food items were consumed.

\section{The inquest.}

Many death stories told for this region often have the caveat that a victim's body by law should be left as it was found till a police officer could be brought to the scene. It is not surprising, then, that on the day following M.P. Durack's actions the body of Philchowski was exhumed by the Wyndham police. The apparent lapse in etiquette on M.P. Durack's part might be explained by the considerable power exercised by station owner/managers of the time. But often enough the police were too far distant to make feasible the normal requirements of law. Jack Sullivan notes, for instance: 'Course he wasn't,'all smashed like. $\mathrm{E}$ was they gotim when e was, just y'know ripe. E was just about stinkin there when they foundim. ${ }^{22}$ And Johnny Walker's version mentions blue flies swarming when the calico covering was lifted off Philchowski. (It is interesting that Wallambain presumably covered the body afterwards. Or was it one of the others?)

\section{Punitive expeditions.}

Incidents of this kind were usually followed by police patrols to enforce European law by apprehending the killer(s). It was usual also for punitive measures to go beyond arrest, trial and gaoling, and the spearing of Philchowski by Wallambain appears to have been no exception. In her newspaper tale Durack alluded to the patrols: 'For three weeks they sought among the hills and gorges and in the pindan ${ }^{23}$ country. Every night the ranges for miles around were dotted with the natives' signal fires as they warned one another. ${ }^{24}$

However by 1983 she had turned up more suggestive evidence:

There is no direct evidence for the sort of retribution often said to have followed the killing of a white man by Aborigines, but . . . [and here she cites a man named Roy Phillips, who wrote to his mother on 20 September, 1913] : 'You will be glad to hear that Philchowski was amply avenged, though I would not say anything about it if I were you. 25

In fact during this decade - and in the decades that immediately preceded and followed - there was a drive on the part of white authorities to round up Aboriginal groups clinging tenaciously to isolated pockets in the region about the Ord river. This took a variety of forms. In about 1907 or 1908 a relatively large group of Aborigines was shot to death on

21 Shaw and Sullivan 1976:251.

22 Shaw and Sullivan 1976:251.

23 Durack 1969:343; pindan, "belonging to the bush or wild country'.

24 Durack 1931.

25 Durack 1983:290. Personal letters are likely to be highly credible says Gottschalk, with the proviso that 'they are less likely to contain the testimony of a skilled observer, since they frequently are intended to exert influence or to create an impression, since they of ten are not private and confidential but are intended for all the members of a family and a circle of friends' and, 'etiquette and convention frequently require expressions of politeness and esteem that may deceive the reader not familiar with the customs of the letter-writers' region (1945:18-19)'. This last warning seems particularly appropriate to our present case. 
Ningbing Station. ${ }^{26}$ Major was hunted down and shot by white police and trackers near Spring Creek in 1908. The tracker Quartpot, who, Johnny Walker tells us, accompanied the Wyndham police to inspect Philchowski's body, also took part in this earlier punitive expedition. In 1909 the roundups of 'bush' Aborigines for cattle spearing, etc. reached a peak, with ninety-five arrests and sentencings. This went on intermittently, with another peak of twenty-six arrests in 1921. ${ }^{27}$ The government ration stations of Moola Bulla ${ }^{28}$ and Violet Valley were founded in 1910 and 1911 respectively. Jim Crisp was speared on Bullita Station in 1919. And in 1926 many Aborigines were killed by a police punitive expedition in the Forrest River area. ${ }^{29}$ Clearly this was a turbulent period in east Kimberley history.

The police party did indeed arrest an Aborigine by the name of Jillambin. They found him near the Keep River - reported in the 1983 version - and he was probably the same person mentioned in the press report of 1931 though his name is not given. Jillambin's trial was held at Wyndham. It lasted four hours. The man was sentenced to death. Roy Phillips said: 'The trial of the blackfellow for the murder of Philchowski did not take long. Parker had a hopeless job trying to defend him, especially with a jury of bushmen. They found him guilty in about three seconds.' 30 In the newspaper version: 'They took him into Wyndham, found him guilty, and imprisoned him.'

There is no further account of Jillambin's final end aside from a brief comment that Wallambain's brother-in-law, who may or may not have been the same man, died at Carlton Hill Station. Jillambin was unlucky to have been found carrying Philchowski's revolver, which made him guilty by association. It was common practice for artefacts of all kinds to be passed from hand to hand through the kinship and ceremonial networks. Jillambin was also said to have been one of the people who remonstrated with Wallambain before the slaying. ${ }^{31}$

Durack introduced another Aboriginal character, who does not appear in any of the other versions of the tale. ${ }^{32}$ The man Boxer, who has his own place in the oral tradition of the region. ${ }^{33}$ reportedly held a grudge against Wallambain and set out in his pursuit. At a sandstone outcrop they had a duel (firearm against spear) in which a bullet fired by Boxer struck Wallambain in the shoulder. Wallambain made good his escape however and later was said to

26 Shaw 1981:36-40.

27 Wyndham Courthouse Records.

28 Alfie Gerrard in his reminiscences gives an especially harrowing account of Moola Bulla life from the perspective of Aboriginal children of the 1930s (Gerrard and Shaw 1987:55-63):

29 Wood 1927/28.

30 Cited by Durack 1983:288.

31 Shaw and Walker 1975:49.

32 Durack 1983:289-90.

33 See for example Shaw 1981:132-4, 1983:158-66, 1986:180-83. 
have worn the bullet around his neck as a trophy. The two men met some time after and settled their differences amicably.

There is further oral testimony that points indirectly to a punitive expedition in the Eight Mile Creek area. From where we stood at Dingo Spring, Joe Nurungin (who died early in 1987) once pointed towards Cockatoo Spring saying laconically that in the early days 'a big mob of blackfellers' was shot there. And Jeff. Djanama told of the spirit of a baby girl that appeared near a hazardous stretch of highway close to the Eight Mile, saying that she had been abandoned in a cave (rock shelter) nearby by her mother when being pursued by the police. ${ }^{34}$ Jeff thought the incident occurred not long before the spearing of Philchowski. Whether or not we can accept a fit between these tales, it is evident that the area around the Eight Mile is reputed to be a place of early-day killings and has its own ghost story.

\section{Endings.}

By now the oral versions of the story have come to an end. Johnny Walker's narrative told to Durack closed with the wrongful arrest of Jillambin. In the version he told me Johnny described how Philchowski's camping gear and horses were disposed of and at my request repeated the circumstances of the spearing. Banggaldun in his version ended with Philchowski's death, stressing the path taken by the spear through the tree fork. On the first telling Jack Sullivan closed the tale at the point where Jim Crisp found the body, but during subsequent proof-reading he noted, as Johnny Walker did also, that Crisp himself was speared to death in later years on Bullita Station.

Durack's versions end on several ironic notes. In the 1931 article Philchowski's military background is confirmed by a letter found among his effects directing him to return to Germany to join the First World War. Durack observed that if Philchowski's life had taken a different turning he might well have met his end on a European battle-field. In her 1983 version she praised the Aborigines stationed at Ivanhoe who cared for the female members of the family in contrast to the dangers presented by so-called 'bush blacks'. Both Durack's versions noted Jim Crisp's later death.

\section{Commentary.}

There are some questions of definition. In its oral form the story has some of the elements of legend. The minimal definition of a legend holds that it is 'a folktale with a simple narrative motif purporting to relate the experiences of real individuals or happenings in the past, the actors in which can be human, supernatural, or both' ${ }^{35}$ (King, 1964:384). Furthermore, such a sage 'may recount a legend of something which happened in ancient times at a particular place - a legend which has attached itself to that locality, but which will probably also be told with equal conviction of many other places'. ${ }^{36}$

Legends are not as reliable as other kinds of testimony, according to Vansina, who groups them with epics and fables as sub-types under the heading 'Tales of artistic merit'. He associates legends with the edifying element, epics and fables with dramatic and imaginative elements respectively. Legends have a historical content which is of ten not allowed to get in the way of a good story, hence he says they are transmitted in an 'uncontrolled' fashion and

34 Shaw 1986:195.

35 King 1964:384.

36 Thompson 1946:8. 
violence can be done to facts. In legends, 'Causes and motivations are invented, and historical personages are given a personality, or imaginary ones introduced'. Yet if the transmission of the legend has been done with care, 'it can serve as a source for the history of the psychological attitudes of a people'. ${ }^{37}$

Our tale does not take place in the remote past but in recent history. It relates the experiences of two principal characters and it is attached to a specific locality. There is an edifying element in that my storytellers were often at pains to have me understand the implications of different episodes. The supernatural element is not present but there is in the written versions an element of mystery about both men - as much a literary device I think as a reflection of what was known about them - while in the oral versions Wallambain is painted as a man with special qualities as a warrior. Here similar motifs are present in other Aboriginal narratives but there is little danger of confusing the Wallambain-Philchowski tale with others.

So the story of Wallambain and Philchowski is not in nature purely legendary, though it does contain elements of legend. It seems better suited to another approach, that of stories classified as 'Tales concerning local history', which are likely to contain material of a 'more exact and coherent' form than that found in general histories. Vansina recommends taking both local and general historical tales together to spell out their links more clearly. ${ }^{38}$

At another level there is the scheme of classification suggested by Muecke, by which tales from the west Kimberley were divided into mythology (called bugaregara), tales of the supernatural (devil stori), and legends (trustori). In 'trustori', 'the characters of the story are human and can be located in time and space, within the memory of the narrator. The heroes of these stories can also perform fantastic acts'. ${ }^{39}$

As I have said already, Wallambain and Philchowski are personages definitely located in time and space. There are written historical records about them. The spearing of Philchowski took place a year after Johnny Walker was brought to the east Kimberley from Darwin as a bny aged between ten and twelve years. ${ }^{40}$ By his own account Johnny heard the tale from other Aborigines, and probably at the time it happened. The 'trustori' quality of the fantastic is not fully developed but there are elements such as surprise and, to European readers, perhaps a touch of the bizarre (for example, the path of the spear through the fork of the tree, the cloud of blue flies, and the desire of another group of Aborigines to view the body).

From my conversations with Johnny Walker there emerged a string of anecdotes on deaths in the harsh north-west environment, often enough brought about by the victims themselves through suicide, arrogant behaviour towards Aboriginal warriors as in Philchowski's case, or as a result of carelessness such as travelling without water. It seems to me that this and other tales like it might be called 'death stories', a subcategory of 'trustori'.

On yet another level: (1) All the versions have a 'common core' about which they largely agree. $^{41}$ (2) It is possible to separate out factors characteristic of the culture from which any given version stems. (3) Interpretations of motive in different versions likewise reflect political viewpoints past and present in the teller's culture. (4) Similarly the characters of the actors in the stories are interpreted according to the cultural backgrounds of the tellers.

\footnotetext{
37 Vansina 1973:159, 160.

38 Vansina 1973:155-6.

39 Roe and Muecke 1983:vii.

40 Shaw 1987:298-300.

41 Cf. Lévi-Strauss 1963:206-31.
} 
In general most inconsistencies in the various narratives may be explained by combinations of the above factors. The main question is not to establish necessarily the 'truth' or 'falsity' of the different versions but to see what the agreements and dissonances tell us about culturally-directed thoughts and actions as they are revealed through the events narrated and the ways in which they are narrated. At the same time certain elements in a tale may appear more likely from two or more alternatives because of agreement between some versions; for example, whether or not the spear was left in Philchowski's body.

Most stories of Wallambain and Philchowski begin by describing an initial confrontation between the two men which establishes motive for the attack. After this the tale moves swiftly from motive to preparations on Wallambain's part and the attempts of kinsmen to dissuade him from taking action, or in one version the role of Aboriginal women in encouraging him to the deed. Then there is the act of the spearing itself, followed by an aftermath: disturbance of the camp, discovery of the dead man, the European inquest and punitive expedition, and a person brought to justice.

In Durack's two accounts most of the suppositions, figures of speech and social relations that are reported have a distinctively European ambience. They are representative also of the periods in which they were written and the style that form of writing called upon. There is the element of privacy of Roy Phillips's letter to his mother. ${ }^{42}$ There is the literary style of the 1931 newspaper article, done with touches of humour and irony that are distinctive to Mary Durack, and the more objective and neutral reportage of her family history.

The oral sources contain also the flavour of Aboriginal culture. The sharpening of the shovel spear is an effective motif relatively common in these sorts of death stories. Here it helps io build up dramatic tension and marks the shift from one episode to another. There is the spearing itself, with the forked-tree motif in some versions. And Philchowski's reactions at the point of death, described so closely as to include the number of times he fired the revolver or spun round, must surely be reported by eye-witnesses.

Durack, who had found no motive in 1931, pursued it in her 1983 version, questioning Johnny Walker and other unnamed Aborigines, who met in a group. ${ }^{43}$ From this she concluded: 'The story that was then unfolded with quiet objectivity seems reasonably convincing. ${ }^{44}$ In this version it is the breaking of a previously held friendship and understanding between the two men over the procurement of women. Wallambain expected prestations of food, etc. under Aboriginal rules of etiquette and was understandably incensed when these were denied by Philchowski. It is a misunderstanding that appears elsewhere in dealings between Aborigines and whites throughout Australia's earlier history as a prime source of conflict. The verbal insults that appear as motive in the other oral versions could be equally inflammatory. Banggaldun's account in its brevity simply omits the prelude to the spearing. Jack Sullivan's testimony on the other hand offers a different cause for enmity, namely Philchowski's drunken firing upon the group of which Wallambain was a member. (During proof-reading Jack gave considerably more detail, which went into the final published version.)

42 Durack 1983:288.

43 These included principally Ernie Chapman, Daylight, Bulla, Mandi, Banggaldun and occasionally Billy Joe (personal communication, Mary Durack). Billy Joe is mentioned in Jack Sullivan's memoirs; see especially pp.83-86 recounting his mistreatment at the hands of police.

44 Durack 1983:288. 
All this faithfully reflects the state of race relations on that 1913 frontier, and some European attitudes of the 1930s. The expectation of a master-servant relationship on Philchowski's part stands out clearly in his dealings with Wallambain: on the one side arrogance and rough-speaking and on the other resentment and a desire for revenge. On both sides of that frontier the final recourse was to force of arms. Those references to 'wanton' damage of the girths and saddles and to cattle-spearing on Wallambain's part ${ }^{45}$ suggest forcefully the nature of a 'guerilla' action of the kind practised by many Aborigines in most parts of Australia. The actions of the two men were wholly consistent with the political context of the time.

The characterisation of Wallambain and Philchowski shows the partialities of the different versions. Durack dwells almost exclusively on Philchowski's character, while that of Wallambain receives greater weight from the Aboriginal narratives. Philchowski is painted as a German aristocrat who is chivalrous towards European women - though his behaviour towards Aboriginal women may have observed other standards - and he is an ex-military officer. This last fact lends credence to the Aboriginal descriptions of his provocative actions. Durack in an end note says that he was a man of quick temper who for that reason lost two jobs. $^{46}$ If we accept this accounting, Philchowski largely brought his death upon himself. But he was unlucky too in the protagonist he chose.

Three independent testimonies confirm the characterisation of Wallambain as a 'man eater'. Grant Ngabidj narrated how Wallambain once leapt into a pool and caught and killed a fresh-water crocodile. Grant remarked that Wallambain, 'was a game-looking old man, a proper bad one, like a policeman. Just like a policeman grabs you and chucks you into a motor car, this bloke would hook up a spear and kill anybody, women or men., ${ }^{47}$ (Grant would then have been about nine years old.) Jack Sullivan speculated that because he was a murderer Wallambain may not have been reborn in the Aboriginal way after his death but may have gone to hell instead! ${ }^{48}$ And Durack noted an Aboriginal report which stressed Wallambain's physical size. He was described as 'that-one-all-a-same-big-fella-boab-tree' ${ }^{49}$ In short, the bundle of traits that we call the characters of the two men might have been sufficient alone to precipitate violence between them.

The foregoing suggests a number of working principles to which we might well adhere when researching Aboriginal (oral) narratives. ${ }^{50}$ (1) It is a distinct advantage to have both

45 Durack 1983:147, 148.

46 Durack 1983:386.

47 Shaw 1981:82.

48 Shaw 1983:141.

49 Durack 1931.

50 Lucas (1986:7) has made the important point that an oral testimony once written down no longer can be called oral. He is right. It then takes a different form, becomes frozen in time and ultimately may represent part of a written tradition with a mystique and authority of its own. On one of my later visits to Kununurra, for instance (in August 1983), there were intimations from members of Grant Ngabidj's close family that they regarded the record of Grant's country of birth Wundarri (Shaw 1981:32) as legitimising in their eyes their own connections to Ningbing Station country. I did not realise it at the time, but in this sense Grant was speaking for his group as much as for himself. Soon after my visit members of the Gadjerung group moved to an outstation near the ruins of the old homestead. 
oral and written testimonies to hand because dates, names and core elements may be corroborated more precisely. Durack's Sons in the saddle was invaluable to the writing of this article. (2) It is helpful also to have a broader context such as a regional history in which to place a focused narrative like that of Wallambain and Philchowski. (3) General works on Aboriginal history and anthropology similarly are valuable, ${ }^{51}$ though I have not made great use of them here. (4) It is important when analysing these tales to take into account their political nature. Hence Wallambain should be numbered with other Aboriginal resistance figures. (5) We should also take into account what Vansina called 'the psychological attitudes in a people's history', along with the events themselves. In fact the insights we have from people's reactions to events are often qualitatively more important than the events themselves - though it is true we would not have one without the other.

\section{Conclusion.}

The tale of Wallambain and Philchowski must be numbered among the few that have come down to us which tell of a confrontation between an Aborigine and a European that ended in success for the Aborigine. Wallambain succeeded in killing Philchowski and in not being caught for it. We are told in one account that he died later at an unspecified time on Newry Station. Against this success we might weigh the unknown cost in lives taken on the punitive expedition and the wrongful arrest and punishment of another man.

In many parts of Australia it is still possible to do this kind of research, in northern communities especially. Such work in its turn becomes source material for other students and helps to generate more studies and insights. For example, several recent writers have used the published narratives of Grant Ngabidj and Jack Sullivan to good effect in the historical analysis of an event, a study of frontier mores, or as sources for ideas on methodology or theory. 52

In other parts of Australia however the task of recording oral traditions like the story of Wallambain and Philchowski, and a host of other topics, is ever more difficult as Aboriginal storytellers of the older generations become fewer in number each year. We found this at first hand when current work began for the Oodnadatta Aboriginal community - in a 'transition zone' with a scant handful of very old persons. We were ten years too late. The present situation in Kununurra is comparatively better though most of the elders with whom I worked have either died since or are prevented through ill health from taking an active part any longer in community life.

On this side of the research frontier ${ }^{53}$ scholars in Aboriginal history have always been very thinly spread over the many topics of anthropological and historical interest. The loss

51 For example Reynolds 1982 or Berndt and Berndt 1964.

52 See Fitzgerald 1984:16-25; Laurence 1984:8; Muecke, Rumsey and Wirrunmarra 1985:84; Rowse 1987:81-99.

53 The 'other side of the research frontier' implied here is represented by those Aboriginal storytellers who become actively involved in joint ventures, collaborative autobiographies etc., to record parts of their tradition for future generations. This notion was well understood, and well received, by the men and women with whom I worked in the east Kimberley. It is acknowledged similarly by Oodnadatta folk. 
of Diane Barwick is sorely felt both as friend and sympathetic researcher. One day our sources will be predominantly the note books of those of us who, like Diane, had the good fortune to do in-the-field recording while that was still possible.

\section{Text.}

Bruce Shaw and Johnny Walker, recorded at Kununurra, 24 and 29 July, $1973 .^{54}$

Right, this is, Phil Firsky [sic] . E was a, e was a German. He workin all over on Ord River everywhere. Rosewood, everywhere. Waterloo, everywhere. So, e go, I think e pulled out. He come in to Wyndham. This chap that we was talkin about that got killed at Bullita, Jim Crisp, he was workin the same place, at Rosewood. A'right. Anyhow, he said, 'What about wait a couple a nights, here? An go down the river an work a couple a, you an I travel together?' You understand? 'Ohh.' this old feller said [in a drawling voice] , e said, 'Ohh I'll fuck along on ahead a you.' E said, 'You catch me up. You smart young feller,' e said to im That's it.

Righto. He left Rosewood, come to Argyle. Wire[?] Yard, come to Argyle. Down, from there from Argyle, to Hicks's Creek. To Thompson Spring, to Cockatoo. When e come to Cockatoo, he went to Eight Mile. This Eight Mile down ere, where the dam site road turn off goin to the, goin to the dam. Just, back just a couple a mile back this way. Might as well say six mile or seven mile back. Righto.

Anyhow e pulled his pack off, just below the road. Below just a minute, 'scuse me. [To himself]. E ad new road on top, the old road in the bottom yeah. [To me]. In between two road anyhow. New road on top side, on Eight Mile, another old road, at the well just there. You might ave noticed it. You went up that road? It's a well in there. Eight Mile Well they call. Used to be. But e fell down. Just sand like. Righto.

An that bloke pull off his pack, on a big, great big h'ironwood tree just like that, with a fork. E's about, fork about that high. An e sort of grow up, you understand? Beautiful shade. Limb all over. Anyhow e pulled is pack off there. An line is pack up. Righto.

He went up an got a billy can a water, burnim[?] leftim inis camp. An e went up an got a lot a fire, made a fire. Put his billy can on, fire. An pull all the dishes out an, well y'know laid is table out. Pulled his knife an fork an beef an tucker out. Ah. A'right.

Righto. Anyhow. E ada, e was makin then, e was makin is tea, old blackfeller come down. Blackfeller calla, Wallambain. E dead at Newry. E's a man eater. Understand? Eat you, eat me. Ah see. That's to murder you, you understand? Murder you, murder me. That's it. What they call a white man, marramballa. That's the white man y'see. You marramballa, me marramballa [marranbalang/nj]. ${ }^{55}$ Well, danmarra[?] they call me different too. I dono what they mean half caste. They callim some other word. Yeah well that's all right.

Well. This old blackfeller come down. E said, I go askim for tobacca.' Is name, is name Wallambain. That feller dead at Newry now. Anyhow this is brother-in-law - e died at Carlton - e said [in a whisper], 'Don't go. Don't go.' E said, 'E might shoot you.' That's it. 'Ah,' e said, 'I'll give it a go. I'll give it a chance.' Right, e left a couple a spear back, oh nearly from ere to that, Grant's camp. E only took one spear an one woomera.

An now, when e heard, this white man look an see this old blackfeller comin. E said,

54 Shaw and Walker 1975:46-54, 109.

55 Kofod 1978:325. 


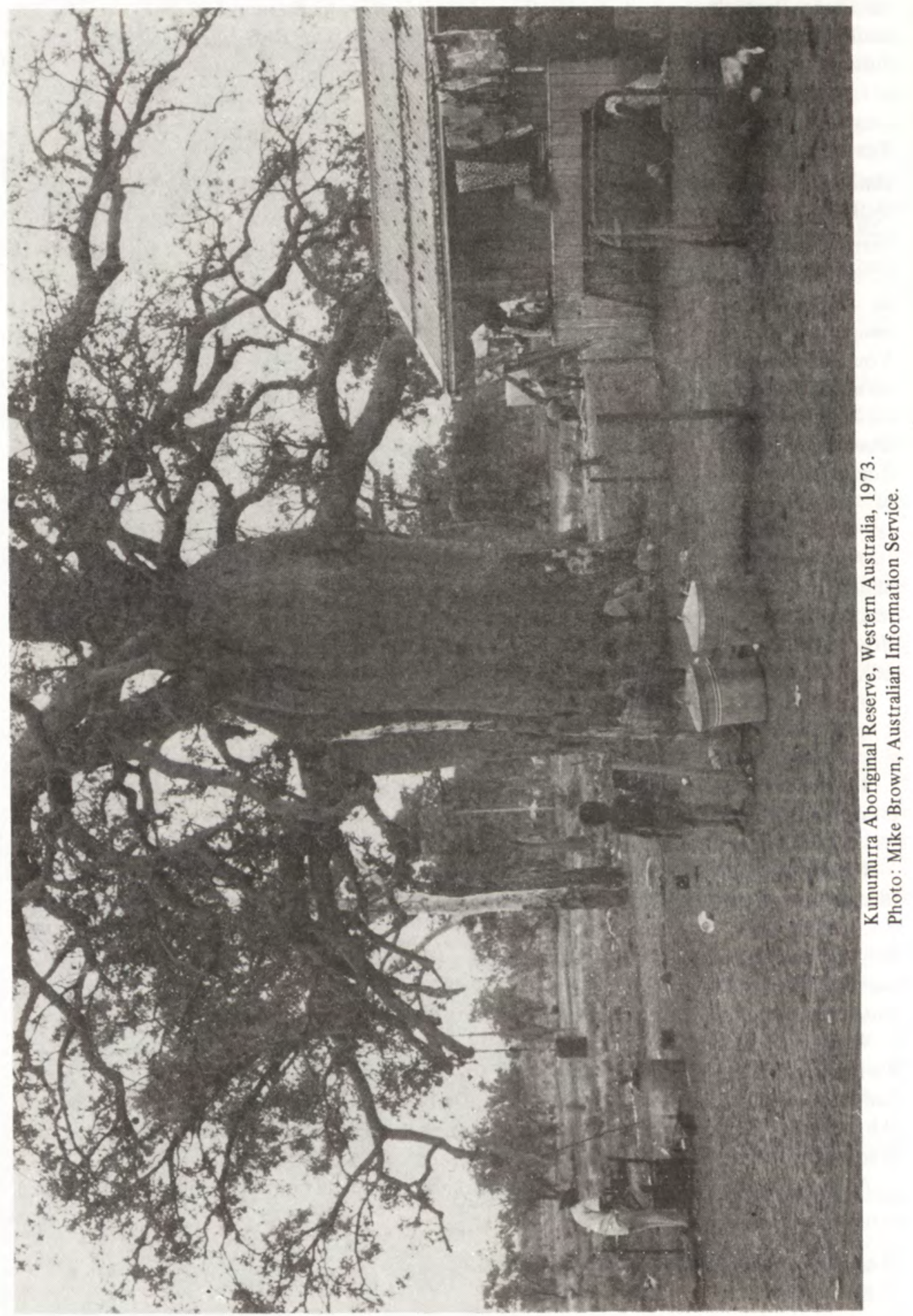


'Goodday.' E said. E said, 'Goodday.' Anyhow, hoho, old blackfeller laugh, 'Ha ha ha ha.' Y'see? That's it. 'You gotta ngundju?' That's the first word e said. Y'know what that mean? 'You got tobacca?' Ngundju. They callim ngundju. Tobacca. That's it.

E said, 'I got no tobacco for a bloody blackfeller like you. Get out, you bloody stinkin old thing.' That's it. Anyhow old blackfeller said, 'Woyawuyangu,' e said to language [I think Johnny was improvising here]. Understand? They talk in the language. E said, 'You cheeky bugger eh?' [wangala, 'be angry,' mad; wariwung, 'cheeky', aggressive] . ${ }^{56}$ See? 'Get out you blackfeller bastard, you too stink.' Well that's it. See? 'Get out.' 'Oh, you woyawuyangu,' e said. So e walked away. Back to is mate, is brother-in-law. E said [in a whisper], 'I'll go back killim that man. Letim tuckout dinner . . . He said, 'No don't you do it.' He said, 'Will only cause you trouble. Police will chase us.' Other bloke said to him like that. 'Ha ha ha ha ha,' he said, 'No-more,' he said, 'Me number one.' That's it.

Ah so he sharpened the shovel spear on the sandstone: sharpen it, sharpen it, sharpen it. Long spear. Well he came up way, look, here this bloke layin down on that, what I was telling you this while ago, with ironwood tree reading a big newspaper... [end of tape] .

E picked up his revolver, all loaded ready. So's accordin to blackfeller, e just went bang, bang, bang. An e counted five shots anyhow that's all. No more about it.

B.S.: Oh so that blackfeller told the story. That's how you know?

Yeah well that's what we was told by, through them. See? I never seen it. But they was just, we biin just told. Righto.

They packed up on Durack Folly range. They was on the Durack Folly range. They packed up, they went over to, what they call stock route, it Four Mile Gap. They went over to another spring. An a, one woman here, is daughter. That feller's daughter - is father died his daughter ere, Mary. Blackfeller callim Yundubain. E was there. An e was only a little lad like, little girl. E said, 'Daddy. Daddy, we wanta go seeim that marranbalang'. Marranbalang's the white man y'understand? 'We no-more savvy what kind im '

All right. There, next morning they all come down. Bloody lucky. Y'know nobody biin on that road. Nobody biin on the road. Anyhow they come down. They took everything what they can, what they can think like. All the tomato sauce they spill it. Waterberry sauce they spill it. Pickle bottle they spill it. Chutney bottle they spill it. They didn't want it. They didn't how how to eat it, you understand? Now they wouldn't spill it. Yeah but why they spill them stuff for, because they want the bottle for spear head. Understand?

B.S.: What mob were these? What people were they?

Ah Miriwung mob. Big Wallambain, this old Wallambain dead at Newry ere. This is is daughter, one of is daughter ere. One a his daughter passed away ere. One a his daughter workin down to, down to Carlton down ere. Another one passed away down ere backa the hill up ere. Long long way anyhow. About ten or twelve mile from ere. Yes well all right.

Anyhow they ada look. All the girl ada look at the marranbalang y'know. Dead one. They pulled the calico up an ada look atim. Righto. They covered im an they took what the best part they could. Tucker line flour tea an sugar. An one boy biin in that moba man, that, e know how to use a rifle. You understand? E know ow to use revolver, e know ow to use 
rifle. E's a stock boy. That's right. But e run away bush. I dono what madim run away for, I dono. Righto.

Anyhow they took the revolver. An this old blackfeller, that, this feller died now, he got the revolver [chuckled], he put it in the hair belt. Just the hair belt you understand? Hair belt. Blackfeller hair belt. He put it in there. He carried the revolver an away they went. Back to the camp. A'right. An they report. Righto.

Anyhow well Jim Crisp come along, two day, three day after. This bloke that was got kill at Bullita. He come along after. An e seeim e can see a moba horses. E seen, horses there belong to whatsaname. Ahh God I can't thinka that feller came now dead there. Anyhow [chuckled] right e said, 'Oh horses still there.' He said, 'Oh e must be round ere.' E look e can see the, see the calico. What they covered im over with the old broken calico. Seen all the pack there an saddle everything, an layin about anyway. Righto. Anyhow.

What's this ahhh ... Ah goodness I can't thinka that bloke's name now. I just called is name not long awhile back. Anyhow Jim Crisp come along. He said, anyhow, he standin on horseback, 'Hey, you avin a good sleep? [Pause]. Hey! You avin a good sleep?' he mentioned his name but I can't thinka his bloomin name. I forget. Anyhow. Oh e jumped off. He jumped off. He lift the calico. He said, 'Hey you avin a good sleep? What's wrong with you?' He lift the cal- oh goodness almighty, thousands a blue flies come out of it. An e look properly, the man got killed! E jumped on, oh e never stopped. He drove the horses there sixty miles an hour, seventy mile an hour must be. [Chuckled]. Drivin them to report to Billy Jones. E was manager. Bill Jones. E died somewhere round bloody New Guinea somewhere. Where e went. I dono where e went where e die.

Anyhow. Well e reports in there. Well e couldn't go away you understand? E found a man. E ad to stay there. They send boy called Alec. E died at Lissadell. They sentim there with a letter. Jim Crisp wrote a letter, an Bill Jones wrote a letter. See Jim Crisp can't report to, Bill Jones. So, what Bill Jones, e told Bill Jones Bill Jones write is own letter. Nother bloke wrote is own letter, when e found im. How e seen im an how e was layin down an all this sorta thing. Righto.

Boy went away that night. Got a horse that night they mustered, they went away, all that night they got there daylight, to Wyndham. To report I think it. Buckland was there I think it. Sergeant Buckland. So report e givim a letter. E said, 'Now put your horse in the police yard,' e said. E ada look at the letter, 'Hm man got kill. By the black, at Eight Mile spring.' That's it. Open another letter, 'Ah this word from old Bill Jones. Ah Jim Crisp report to Bill Jones. Oh that's all right.'

Righto. 'Quartpot an Killy, muster them horses up putim together.' He said, 'Man got, passed away up there we gotta go an, ava look atim.' Righto. 'Pack up a sulky.' Police on the sulky. Only one tracker. An sergeant stop back. An another bloke, nother tracker stop back. Three policemen was in Wyndham. Two stop back an one come out. They come out. Out there, at Ivanhoe. They pick up Jim Crisp. They left the horses there an the pack an everything. They took Jim Crisp out withim. Two police boy. An I think two more boys from Ivanhoe. Went out with them, to givim hand.

An out there, where e buried. They buried im just ere not far off is, off to where that tree where they killedim.. Just there, If I ada good eye I can take you with the motor car if you got a motor an take you show you all that places. Yeah well a'right.

Anyhow now, the police ada look at it an done somethin an that's all. They got all the pack. They putim on the sulky all you know. The, halfa the gear not worth it like y'know. 


\section{WALLAMBAIN AND PHILCHOWSKI}

That bita broke up gear e not worth it. You might as well chuckim on the rubbish heap. Ah half the pack an half the saddle was all right. Righto. An anyhow.

Well station boy, got them horses belong to Philchowski. They drovim down, two Ivanhoe boy, into ere like. See, to Ivanhoe. An they bury, after they buried the man like, police come back. So. Ah, this Jim Crisp, e was there at Ivanhoe. While them boy brought them horse poli- ah, ohh goodness what that man name anyhow? Ah brought that horses down to Ivanhoe. Then ah, this, this like a, this police boy, one police boy stop there. One went on. I dono which one stop, might be Quartpot might be Killy. Well then, when it was, Jim Crisp like took them horses down. Y'know takim to Wyndham for sale. See you might as well get rid ofim. It's no good keepin. Givim to somebody else. Yeah. Well that's all right. That finish. That part finish... [pp.46-54].

B.S.: Philchowski was under the ironwood tree reading a big newspaper? ${ }^{57}$

Yeah. That's what they say y'see.

B.S.: An, Philchowski had a revolver?

Yeah.

B.S.: Now, I missed that part. How did Wallambain kill Philchowski?

Well e kill e, y'see e ad is bed. Like say I got a a bed like that. I got all, I might ava, I might ava squirt [pistol] ere y'understand. When e killedim e sorta, 'Hooooh.' Well e sorta, well accordin to they, what word what we heard y'see, through them. He sorta swinga, 'Ohhhh.' He sorta swear e said, 'You black bastard.' He spins around like this [matching action to word]. He picked the revolver. Bashes [?] this he went that way you understand? Bang bang bang bang. Well I say, the $[\ldots . ? .$.$] pick the revolver an got too much you understand. You$ only got five bullet in it.

B.S.: An Wallambain threw the spear at him?

Oh e shotim first. E killedim first.

B.S.: With the spear?

Yeah, yeah. E killedim first. Then e, sort of fall down, y'see. I s'pose when e tap im e pull the spear out an e run away y'see? E musta done that way. See e never left no spear on it. You understand? E might be, go through here, like up here some way. Hm? A shovel spear y'know, very very y'know very shovel h'iron. Course you know yourself what sort of iron it is, shovel. [p.109].

57 When I was recording these versions more than ten years ago a group of us on one occasion visited the Eight Mile, but we could not ascertain the exact spot where the encounter took place. One tree had indeed a forked branch but aside from that it was little more suggestive of the real site than any other tree. We did establish however that the place of the killing was not at Philchowsky's Crossing itself but about half a kilometre further south, close to one of the old cattle roads, which could just be made out between the trees. 


\section{ABORIGINAL HISTORY 1987 11:1}

\section{BIBLIOGRAPHY}

Berndt, Ronald and Catherine Berndt. The world of the first Australians. Sydney, 1964.

Durack, Mary. 'Rudolph Philchowski: tale of a north-west tragedy', West Australian, 16 May, 1931:5d. The rock and the sand. London, 1969.

Sons in the saddle. London, 1983.

Fitzgerald, Brian. " Blood on the saddle": the Forrest River massacres, 1926', in Bob Reece and Tom Stannage eds, European-Aboriginal relations in Western Australian history, pp.16-25. Nedlands, 1984.

Gerrard, Alfie and Bruce Shaw. 'The discrimination was so thick', in Bill Gammage and Peter Spearritt (eds), Australians 1938, pp.55-63. Broadway, NSW, 1987.

Gottschalk, Louis, Clyde Kluckhohn and Robert Angell. The use of personal documents in history, anthropology and sociology. New York, 1945.

King, Arden. 'Legend', in Julius Gould and William Kolb, eds, A dictionary of the social sciences, p. 384. London, 1964.

Kofod, Frances. The Miriwung language (east Kimberley): a phonological and morphological study. MA thesis, University of New England, Armidale, 1978.

Laurence, Caroline. Aboriginal identity: the contribution of a mission home. B.A. (Hons) thesis, University of Adelaide, 1984.

Lévi-Strauss, Claude. Structural anthropology. London, 1963.

Lucas, Rodney ed. Resources for Aboriginal family history. Canberra, 1986.

Muecke, Stephen, Alan Rumsey and Banjo Wirrunmarra. 'Pigeon the outlaw: history as texts', Aboriginal History 9 (1), 1985:81-100.

Pedersen, Howard. '“Pigeon": an Australian Aboriginal rebel', in Bob Reece and Tom Stannage eds, European-Aboriginal relations in Western Australian history, pp.7-15. Nedlands, 1984.

Pye, John. The Port Keats story. Kensington, NSW, 1973.

Reynolds, Henry. The other side of the frontier: Aboriginal resistance to the European invasion of Australia. Ringwood, Vic., 1982.

Roe, Paddy and Stephen Muecke. Gularabulu: stories from the west Kimberley. Fremantle, 1983.

Rowse, Tim. 'Were you ever savages?' Aboriginal insiders and pastoralists' patronage. Oceania, 58 (1), 1987:81-99.

Shaw, Bruce. My country of the pelican dreaming: the life of an Australian Aborigine of the Gadjerong, Grant Ngabidji, 1904-1977 as told to Bruce Shaw. Canberra, 1981.

Banggaiyerri: The story of Jack Sullivan as told to Bnice Shaw. Canberra, 1983a.

'Heroism against white rule: The "rebel" Major', in Eric Fry ed, Rebels \& radicals, pp.8-26. Sydney, 1983b.

Countrymen: the life histories of four Aboriginal men as told to Bruce Shaw. Canberra, 1986.

Bush time, station time: two east Kimberley Aboriginal men, reminiscences of eighty years as told to Bruce Shaw. Typescript, 1987.

Major and Nemarluk, in Northern Territory Dictionary of Biography. Darwin forthcoming.

and Banggaldun Balmirr. Banggaldun Balmirr. Conversations May 1970-May 1982. Typescript, 1982.

and Jack Sullivan. Sullivan, Jacko. Northman, Jack. A man of mixed Miriwong-European descent. Conversations October 1973-October 1974. Typescript, 1976.

and Johnny Walker. Walker, Johnny. Djimara. A part-Aboriginal man. Conversations July 1970December 1973. Typescript. 1975.

Thompson, S. The folktale. New York, 1946.

Vansina, Jan. Oral tradition: a study in historical methodology. Harmondsworth, 1973.

Wood, G.T. 'Report of Royal Commission of inquiry into alleged killing and burning of bodies of Aborigines in east Kimberley, and into police methods when effecting arrests'. Printed Papers, Reports, etc. of the Parliament during the First Session of the Thirteenth Parliament, Paper no.3. Western Australia. Parliamentary Papers vol.1. Perth 1927/28.

Wyndham Courthouse Records. Court of Quarter Sessions, Minutes February 1906-February 1927. Library Board of Western Australia (Battye Library Archives), 1906-1927. 